\title{
Common INSECT GALLS of Saskatchewan
}

\author{
BY J. D. SHORTHOUSE*
}

Seldom does one walk in the outdoors without coming across abnormal growths on the leaves or stems of various plants. "Pine cones" on willows or "marbles" on rose stems have captured the curiosity of most of us. If we open one of these structures, we will find the larva of a tiny insect nestled at the centre. Such is the world of the gall insects, a select group of specialized insects that have evolved the amazing ability to regulate growth patterns of plants to their own advantages. The "pine cones" or "marbles" are actually plant structures caused by the feeding activities of the larvae of gall insects. Some, as yet unknown, substances in the larva's saliva cause the plant cells to enlarge and multiply rapidly. The insect is thereby surrounded with thick layers of nutritive plant matter. The plant not only supplies the insect with an abundance of food, but also provides protection from rigours of the environment and a shelter in which to pass the winter. The thick walls of the gall also give the helpless insect some protection from predators.

Insect gatls are better known to people than are the insects that produce them. Galls are often noticed because of their abundance, colour, or grotesque size and shape. On the other hand, the gall insects are usually small and difficult to identify. Well over 1,500 different species of gall-forming insects have been described from North America and about 100 different kinds probably occur in Saskatchewan. The gall making habit occurs in six orders of insects: beetles (Coleoptera), moths (Lepidoptera), thrips (Thysanoptera), aphids (Homoptera), flies and midges (Diptera), and sawflies and cynipid wasps (Hymenoptera). About $55 \%$ of

*Department of Biology,

University of Saskatchewan,

Saskatoon, Saskatchewan. the galls are caused by flies and midges and $35 \%$ by cynipid wasps. Little is known about the insect galls of Saskatchewan and, in fact, a preliminary checklist has yet to be made. In this article only the most common insect galls are discussed.

One characteristic of gall insects is that they are very host specific, that is, each species of gall insect always forms galls on the same species of host plant. For some unknown reason certain plants are more attractive to gall formers than others. In Saskatchewan the plants with the most gall insects are the willows, poplars, roses and goldenrods. Large numbers of gall formers are associated with the oaks which have a restricted distribution in this province and this is one reason why Saskatchewan has few kinds of galls compared to other areas of North America. Gall insects are also very specific as to the part of the plant they attack. Galls are found on the roots, stems, flowers, buds, leaves and petioles depending on the species of insect. The host plant and the part attacked usually are characteristic of the insect species and this information is very useful in making identifications.

Another interesting aspect of gall insects is that each species of insect produces its own kind of gall, which is remarkably constant in size and shape. There are two basic types of galls: open and closed. The open galls are considered the more primitive. Those formed by aphids (Fig. 1) are a good example. In the spring aphids begin feeding on the outside of the poplar leaves and as a result of their feeding, cause the leaf to fold and grow inwards to produce a pocket in which they live and feed. Young aphids are produced inside the galls and once they mature and develop wings, they escape through natural openings in the gall. Closed galls are 
caused by the larvae of beetles, moths, flies, sawflies and cynipid wasps. These insects lay eggs on or within healthy parts of a plant and their larvae then cause the gall to be formed. The goldenrod ball gall (Fig. 3 ) is one of the most common examples of a closed gall. In some parts of Saskatchewan nearly every goldenrod stem will have one or two galls. The female flies (Fig. 15) lay their eggs upon the young goldenrod stems in the spring and the gall appears a few weeks after the larvae (Fig. 14) have begun to feed on tissues of the stem. The larvae are full grown by fall and remain inside the gall throughout the winter. As soon as the snow has melted in the spring, the larvae change into pupae and about a week later the adults emerge and the cycle is repeated. More advanced insects such as the cynipid wasps form galls of greater complexity than those of aphids. Some rose galls are as large as apples while the insects that cause them are smaller than apple seeds.

\section{Insect Gall Communities}

Many insects besides the gall-formers often are associated with galls. Plant feeding insects are attracted to the concentrations of nutritive plant cells and parasitic insects attack and feed on the larvae of the gall formers. Another group of insects, closely related to the cynipid wasps (Fig. 12), cannot form their own galls, but instead lay their eggs inside the galls of other insects (Fig. 20). During the laying process the larvae of the gall-formers are killed. When the larvae of these insects, called "inquilines" (from the Latin word for "guest"), begin feeding on the walls of the gall, they too stimulate the cells to grow and as a result each larva is enclosed in its own 'gall within a gall' (Fig. 21). The increased number of insects inside the modified gall attracts even more parasites.

The group of insects associated with galls formed by a particular species is an excellent example of a simple insect community. Studying these insects, one is exposed to nearly all aspects of community ecology. If you examine galls at various times throughout the summer, you will see that the numbers and kinds of occupants change as the season advances. Ecologists call this change "succession." When the season draws to a close and no further changes occur, the community is referred to as having reached its "climax." If one determines the feeding habits of the gall inhabitants, a food web can be constructed: for instance, when the gall formers and inquilines (guests) feed on the plant tissues and they in turn are fed upon by the parasites. Often a parasite will itself be attacked by another parasite. But in gall communities, the key character is always the gall former, for without the gall, none of the other species could exist.

\section{Studying Insect Galls As A Winter Project}

Most Saskatchewan students and naturalists would agree that they are restricted in the kinds of biology projects that they can attempt during the winter. Insect gall studies are an exception, for not only can some galls be collected and studied during the winter months (those of Figs. 2, 3, 4, 7, 8 and 9 ), but they are actually easier to find when the leaves have fallen and the background is snow. If at least 15 galls of one kind are collected in the winter and brought indoors, the insects, thinking it is spring, will begin emerging within about 3 weeks. Galls with holes indicate that the occupants have already emerged. Glass jars make good rearing containers and when the insects crawl to the lid, they can be easily removed with a small moistened brush. A great deal can even be learned about communities by examining these galls through the winter. To observe community succession, arrange a series of about $2 \mathrm{C}$ vials (pill bottles) containing alcohol near the rearing jar. At the end of the day place all the emerged insects in a vial, use a different vial each day and mark the date on it. Comparison of numbers and kinds of adults from the first few days of the cycle with those near the end will illustrate succession. It is interesting to note than in most rose gall communities the gall formers are the least common of the insects 

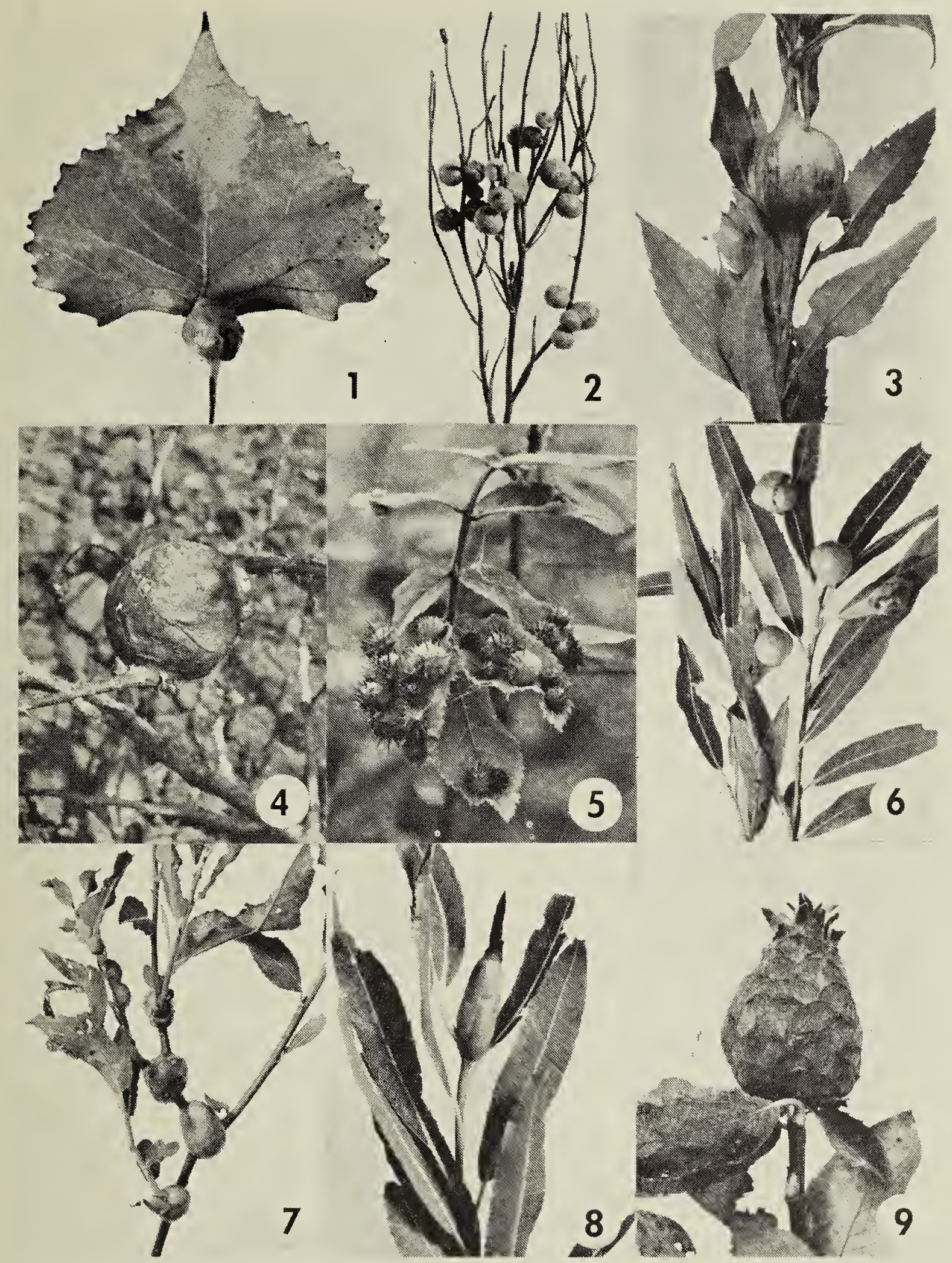

igs. 1 to $9-$ Common insect galls found in Saskatchewan.

ig. 1. Poplar leaf gall caused by aphids of the genus Pemphigus.

ig. 2. Skeleton Weed Lygodesmia juncea galls caused by larvae of the cynipid wasp Antistrophus pisum.

ig. 3. Goldenrod ball gall caused by maggots of the fly Eurosta solidaginis.

ig. 4. Rose stem gall caused by larvae of the cynipid wasp Diplolepis multispinosus.

ig. 5. Rose leaf galls caused by larvae of the cynipid wasp Diplolepis polita.
Fig. 6. Willow leaf galls caused by larvae of the sawfly Pontania pomum.

Fig. 7. Willow stem gall caused by larvae of the midge Rhabdophaga batatus.

Fig. 8. Willow bud gall caused by larvạe of the midge Phytophaga rigidae.

Fig. 9. Willow cone gall formed at the tips of shoots by larvae of the midge Rhahdophaga strobiloides. 

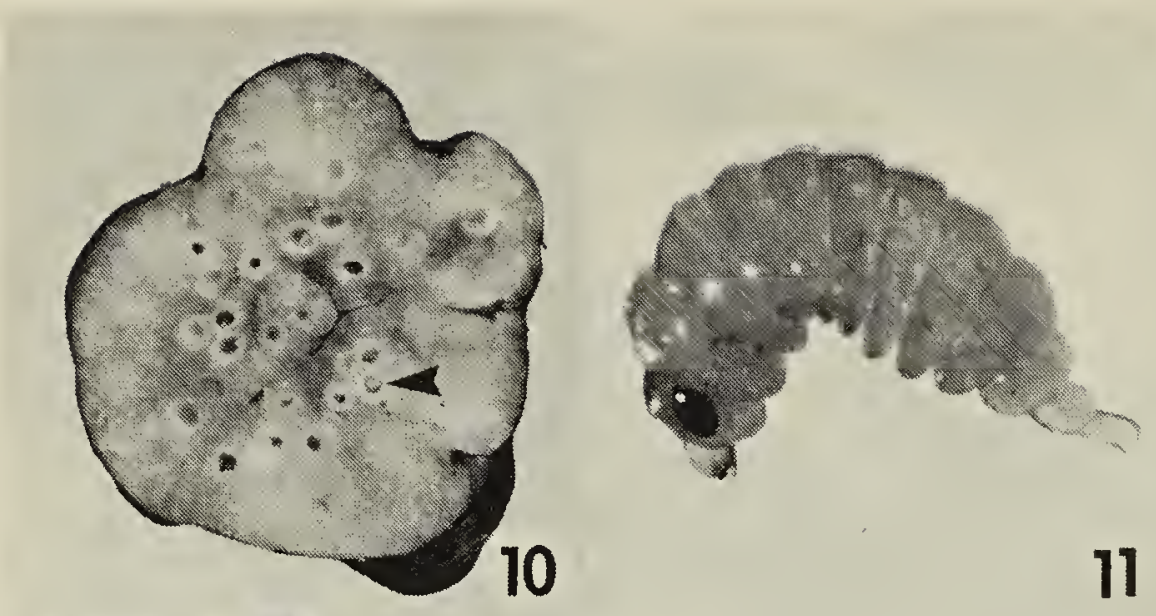

11
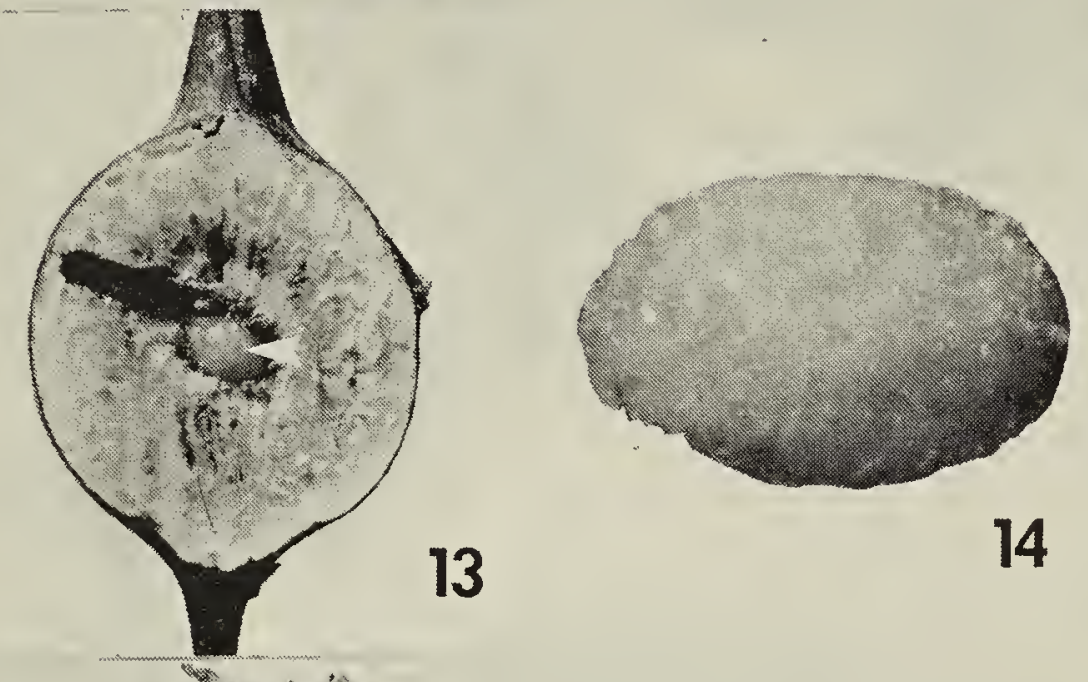

\section{4}
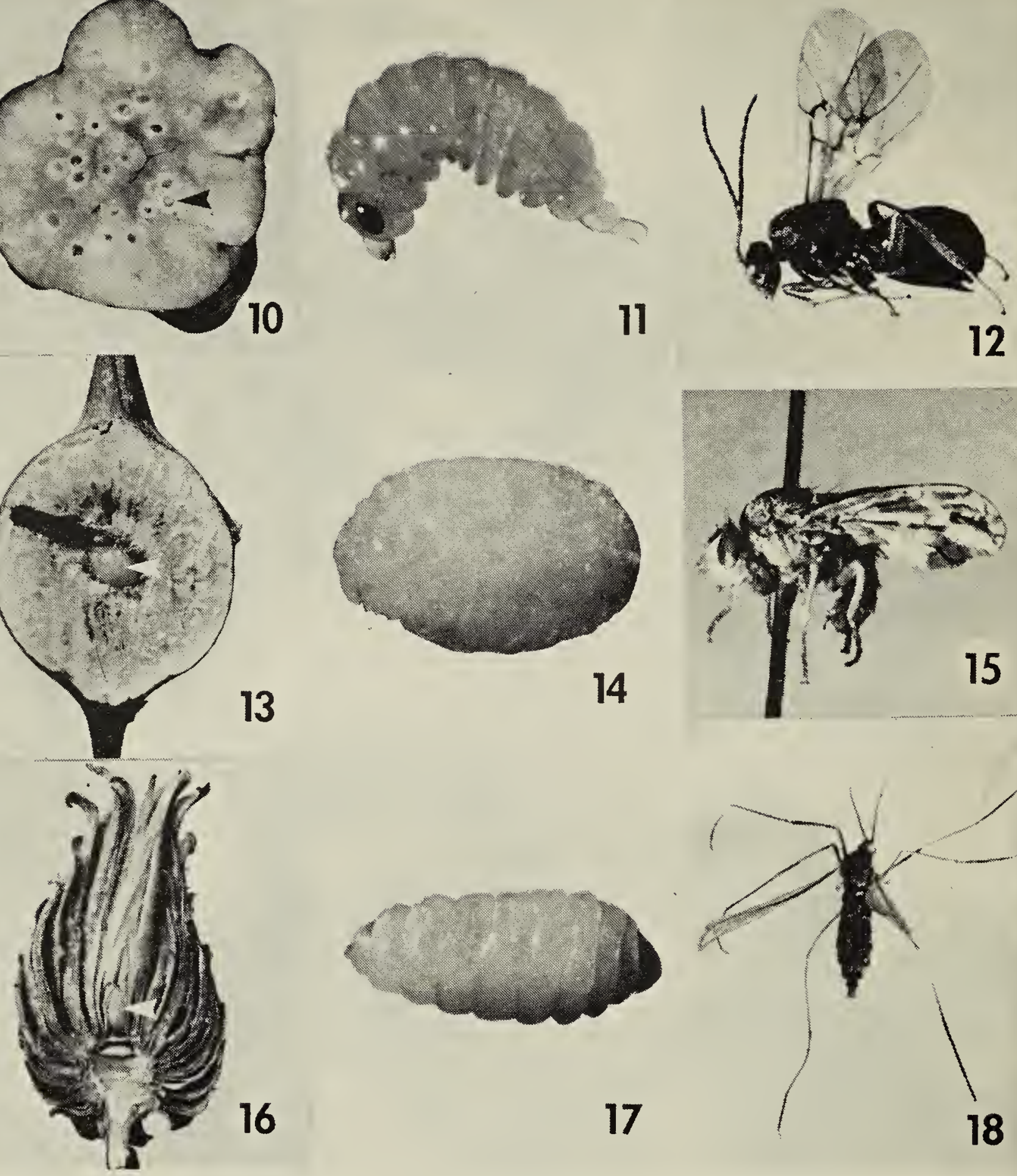

12

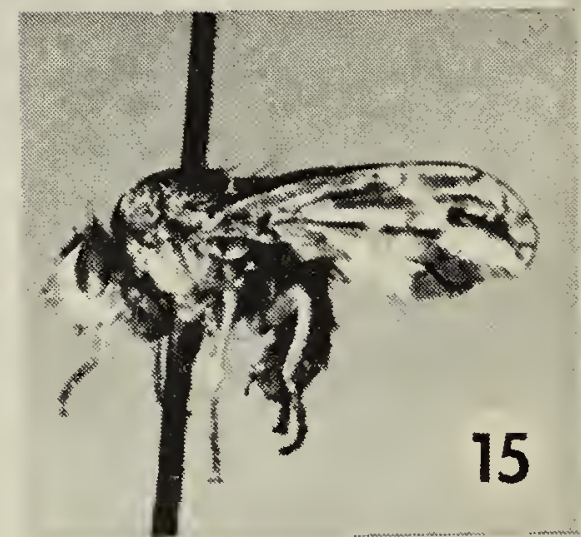

17

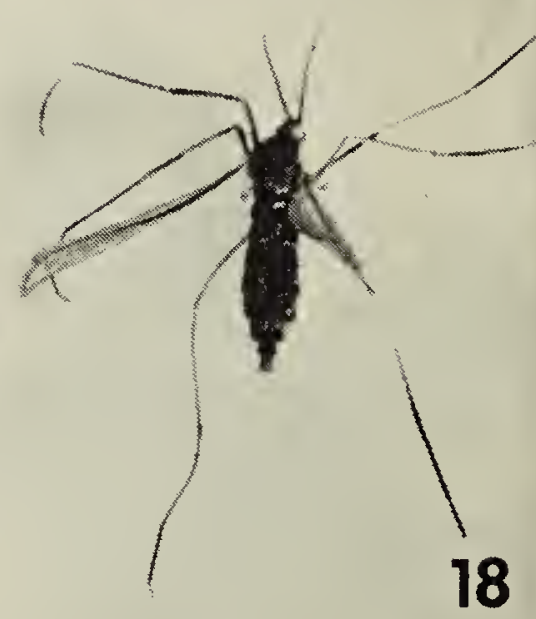

Figs. 10-18. - Dissected galls showing position of the gall-forming larvae and enlarge photographs of the immature insects and their adults.

Fig. 10. Opened rose stem gall showing numerous chambers occupied by cynipid wasp larvae (see arrow).

Fig. 1 1. Larva of the cynipid wasp which forms the gall shown in Fig. 10. The adult eye is beginning to develop, indicating that the pupal stage is near.

Fig. 12. Adult cynipid wasp of the larva shown in Fig. 11 .

Fig. 13. Opened goldenrod ball gall showing the gall-forming maggot at the centre (see arrow). Note that the maggot has chewed a channel to the outside of the gall. This will be the escape route of the adult fly, which has inadequate mouthpart chew through the gall tissues.

Fig. 14. Maggot of the fly which forms the shown in Fig. 13.

Fig. 15. Adult fly of the maggot shown in Fig.

Fig. 16. Opened willow cone gall showing posit of the gall-forming midge larva (see arrow).

Fig. 17. Larva of the midge which forms the shown in Fig. 16.

Fig. 18. Adult midge of the larva shown in Fig. 

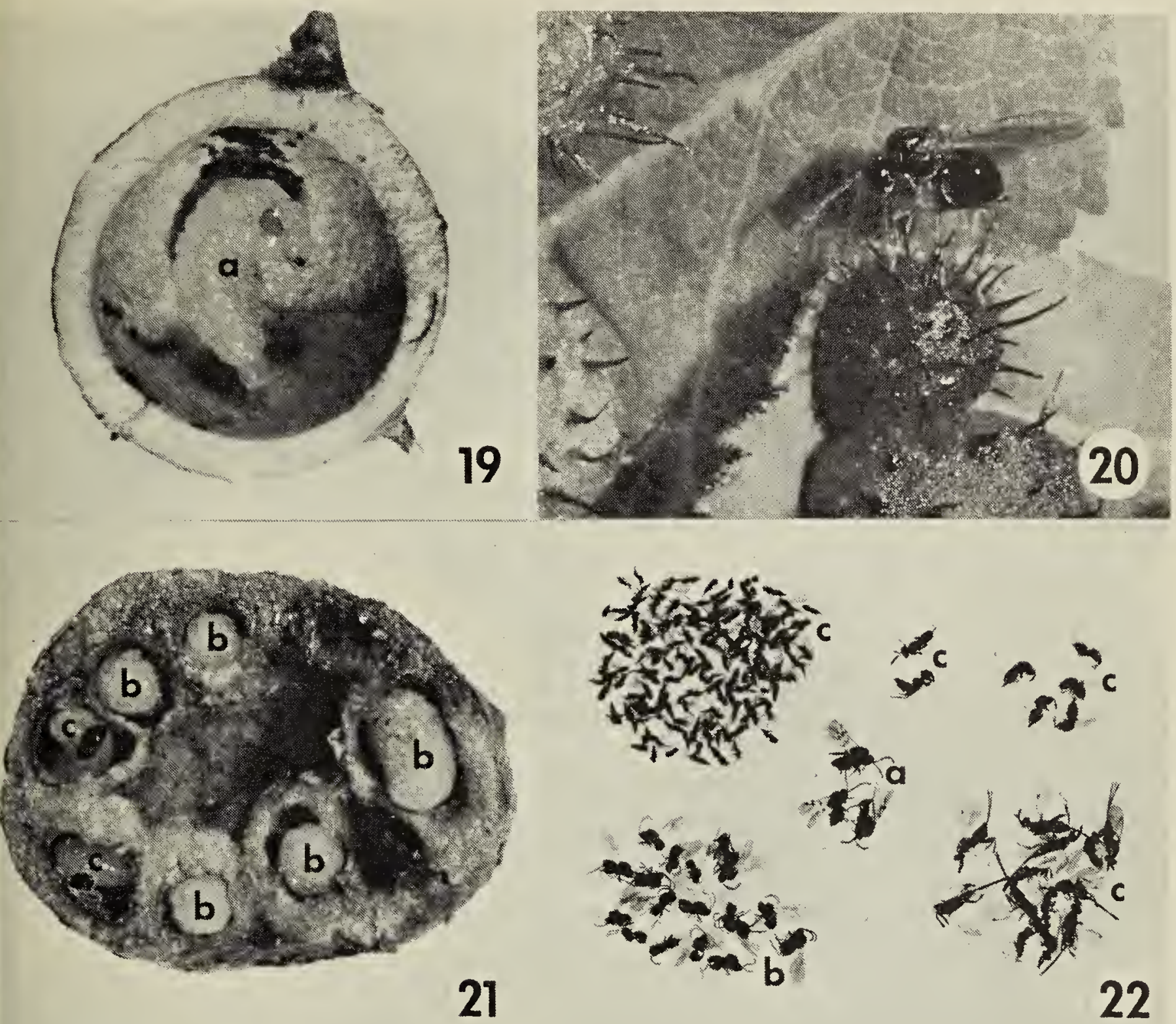

igs. 19-22. Example of a simple insect gall community illustrated by inhabitants of the leaf all shown in Fig. 5.

ig. 19. Normal gall caused by a single larva (a) of the cynipid wasp Diplolepis polita.

ig. 20. Inquiline cynipid wasp laying eggs in an immature gall of $D$. polita.

g. 21. Gall of $D$. polita modified by the larvae (b) of the inquiline cynipid wasp shown ovipositing in Fig. 20. Some of the inquiline larvae have been attacked and eaten by the larvae of parasites (c).

merging (Fig. 22) and the parasites are ie most common. The succession obserd indoors will cover a shorter period tan it actually takes in nature, but the umber of emergents and the order of heir appearance will be the same.
Fig. 22. Food web of the D. polita gall community. The gall-forming cynipid wasps are in the centre (a) and the gall-modifying inquiline wasps are to the lower left (b). Four species of parasitic wasps (c), whose larvae feed on the larvae of the gallformers and the inquilines, are shown above and to the right of the gall-formers. Note that the number of gall-formers that survive is much smaller than the number of inquilines and parasites. 


\section{Acknowledgements}

I wish to thank Mr. J. Waddington, University of Saskatchewan photographer, for his help in making the plates and taking most of photographs. Information in this article is from part of a research project financed by the University of Saskatchewan's Institute for Northern Studies and by a National Research Council of Canada grant held by D. M. Lehmkuhl. Preparation of this article was sponsored by the Entomological Society of Saskatchewan.

\section{USEFUL REFERENCES}

Darlington, A. 1968. The Pocket Encyclopaedia Plant Galls. Blandford Press. London. 191 pages

Felt, E. P. 1940. Plant Galls and Gall Makers Comstock Publishing Company. 364 pages Reprinted 1965 by Hafner Publishing Compan Inc. New York.

Hutchins, R. E. 1969. Galls and Gall Insects. Dodd Mead and Company, New York. 128 pages.

Mani, M. S. 1964. Ecology of Plant Galls. W. Junk Publishers. The Hague, Netherlands. 434 pages

Shorthouse, J. D. 1973. The Insect Communit Associated With Rose Galls of Diplolepis polit (Cynipidae, Hymenoptera). Quaest. ent. In pres

\section{1st ANNUAL \\ SASKATCHEWAN CHRISTMAS BIRD COUNT 1972}

\section{Compiled by MARY I. HOUSTON*}

Perhaps the generally mild weather over the count period was an encouraging fac tor in the record high of 46 localities reporting for the Christmas Bird Census thi year. Fifty-five species were seen on count days with an additional 6 species seer during the count period. A Ruby-crowned Kinglet identified at Biggar by Dor Renaud adds a new species to the all time list, bringing the total to 115 species witl 6 additionals.

Especially interesting records included the two Hooded Mergansers seen at Gar diner Dam by the Renauds. This species has only been recorded once previousl when in 1960 Ross Lein and Darrel Carlson saw three at Estevan. A Borea Chickadee seen at Wauchope by Dale Hjertaas during the count period wa unusually far south. Unfortunately, the only Gyrfalcon seen during the period (a Belle Plaine, Dec. 20, by Bob McCall) was not in a bird count. There was only Bald Eagle report this year, at Squaw Rapids. White-breasted Nuthatches seeme more common than usual, being reported from five localities, while Red-breaste Nuthatches were reported from only one locality. Snowy Owls seemed to be in large numbers (e.g., 13 at Harris) in many of the 21 areas in which they were seen. On th other hand, Gray Partridge, which a number of counters felt had decreased greatl in number, were seen in 25 areas, though probably in lower numbers than usual i each area. Ravens were reported from more southern localities (Broadview, Harri: Raymore, Saskatoon, Spirit Lake) than usual.

Special commendation goes to Wayne and Don Renaud who arranged five count and Wayne Harris who arranged four.

BANGOR, Dec. 31 ; temp. $-20^{\circ}$, sunny; 8 species, 54 individuals. - Mrs. A. Thompson.

BIGGAR, Dec. 16; temp. 20, light cloud, wind light, 3 in. snow: 11 species, 2699 individuals. (Add: Snow Bunting, 1500, Dec. 22). - Don Renaud, Wayne Renaud (compiler).

*863 University Drive, Saskatoon.
BIRCH HILLS, Dec. 27; $9 \mathrm{mi}$. by car in hour, temp. $20^{\circ}$, overcast, calm, 8 in. snow species, 446 individuals. (Add: Ruff Grouse, 4, Common Raven, 9, Eveni Grosbeak, 9). - Moe Mareschal.

BORDEN, Dec. 30; 2 mi. on foot in 1 ho and $79 \mathrm{mi}$. by car in $5-1 / 2 \mathrm{hrs}$, temp. $-17^{\circ}$ $2^{\circ}$, wind $E 8$ to $0 \mathrm{mph}$, cloudy with aft noon fog; 13 species, 1442 individuals. and Vic Harper, John Shadick, Stan Shadi (compiler). 